\title{
MULTI-CRITERIA EVALUATION OF BEAUTY IN ARCHITECTURE
}

\section{Bogusław Szuba}

University of Applied Sciences in Nysa

boguslaw.szuba@pwsz.nysa.pl
A B S T R A C T

The article deals with the problems of beauty in architecture found in various layers of meaning related to: $(*)$ the creative idea of the planned investment; $\left(^{*}\right)$ the ability to determine the right place for the planned investment, harmonising architecture in the space of the location with special consideration of the natural environment; $\left(^{*}\right)$ communication and information with the environment; $(*)$ respect for tradition and custom cultivated in the local socio-cultural environment, paying attention to the historical continuity and coherence of the architectural forms used; $\left({ }^{*}\right)$ creativity of shaping space; $(*)$ precision and innovation of the functional and used spatial solutions; $\left(^{*}\right)$ partnership relationship with the neighbourhood; (*) broadly understood of participation in the investment process; (*) giving meanings triggering the philosophical message and transcendence; (*) proper use and management; (*) achieving social and cultural goals; $\left(^{*}\right)$ ability of planning the transformation / revitalising existing architectural objects.

The research method is the analysis of listed components based on literature sources and examples of architectural objects or urban complexes.

The considerations lead to the thesis: Beauty in architecture is a state of harmony of aesthetic and utilitarian values of the shaped space in the relations of a creative response to broadly understood conditions of the local, natural, socio-cultural and built environment.

KEY WORDS

BEAUTY IN ARCHITECTURE

CRITERIA OF BEAUTY IN ARCHITECTURE

HARMONY OF ARCHITECTURE AND ENVIRONMENT

PHILOSOPHY OF ARCHITECTURE

AESTHETICS OF ARCHITECTURE 


\section{INTRODUCTION}

Man is a part of the natural world, at the same time influenced by the systems of values professed in the family, in religious groups, or in the nation. The concept of beauty can vary among nations, social strata, and even individual people. To a large extent, this is a subjective feeling, extremely difficult to verify, sometimes very fleeting, depending on the individual experience of the perceived environment.

However, there are premises indicating the existence of objective beauty, contained in the natural world or in the human world shaped by the Creator, guided by the creation of good and fully valuable things.

Phenomena occurring in nature may be the key to perceiving and learning about beauty, which positively inspires people in shaping the environment. It can be presumed that this influence will result in the formation of relationships and relations of the elements of the environment that cause the perception and beauty of the users to be shaped.

The symbol of beauty can be a man with harmonious, perfect proportions of his body. ${ }^{1}$ Beauty is also contained in the depths of human personality. It manifests itself in the noble deeds of man, the attitude and conduct of behavior towards others. Beauty also manifests itself in the human community, whose functioning is based on partnership, mutual understanding, cooperation, devotion or consecration.

\section{CRITERIA FOR ASSESSING BEAUTY IN ARCHITECTURE}

Beauty in architecture can be seen in a single object, as well as in its relationship with the immediate surroundings. Criteria 1-6 relate to the values that testify to the different understanding of beauty regarding an architectural object itself and have been associated with the values of beauty found in a human person. Criteria 7-12 are related to the values indicating a multitude of understandings of the beauty of the object in relation to its surroundings and have been linked to the values of beauty manifested in the family or in human society.

In the author's conviction, the critera list for assessing beauty in architecture can be almost inexhaustible. Everyone has a different perspective on the phenomenon of beauty in architecture. The chosen criteria are inseparable from the investment process cycle. 


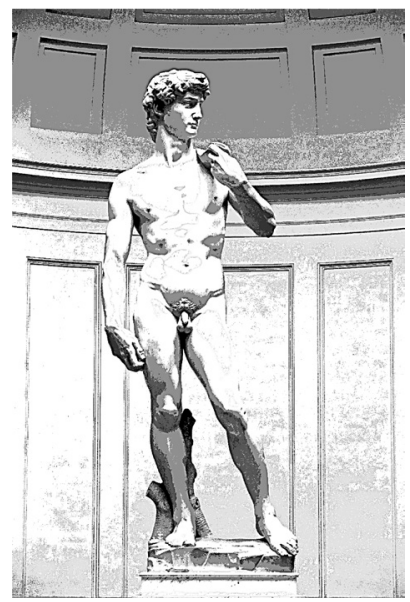

Fig. 1. 'David' by Michelangelo. Author's elaboration on the basis of illustration published in: https://pl.wikipedia.org/wiki/Dawid_(rze\%C5\%BAba)\#/media/File:\%27David\%27 by Michelangelo_Fir_JBU005.jpg. 


\section{1) The Beauty of Being Yourself Versus the Creative} Idea of The Planned Investment

\begin{tabular}{|l|l|}
\hline MAN & ARCHITECTURAL OBJECT \\
\hline The beauty of the purpose of human action; & The beauty of the purpose of the investment \\
The beauty of being yourself, manifesting & project; \\
your individuality in an individual way. & $\begin{array}{l}\text { The beauty of the creative plan of the } \\
\text { planned investment, identification of its } \\
\text { distinctiveness, originality and creative impact } \\
\text { on the environment. }\end{array}$ \\
\hline
\end{tabular}

\section{Man}

The beauty of being yourself, beauty begins when you decide to be yourself. Nature prolonging life does not make clones, it does not repeat and does not copy in a mindless way. The beauty of the natural world consists in the harmonious relationship between homogeneity and the diversity of living beings. Each of the people has individual personality traits, learned behaviors and tendencies. Although all people have the same physical structure belonging to the two genders, we can distinguish each individual characteristics facial features, the geometric silhouette construction, hair colour, physical fitness, etc. What's more, we are able to see in each human person a unique individual beauty, not only material based on impeccable body structure, but also spiritual, connected with the human psyche, the strength of character, gift of friendly relations etc. Manifesting the individuality of each human person is at the root our existence. Everyone lives on their own account, sometimes imitating the behaviour of their idols, but ultimately wanting to implement their own life plan, and making their own decisions. At the same time, we want to be a person who is well received and noticed in the closest surroundings, perform certain roles in it, be useful and useful. This is the realisation of the beauty of being yourself. However, before it is fulfilled in the human mind of a child, then a man growing up and an adult, this vision is born, develops and ultimately subject to realisation.

The concept of being yourself requires renewal. Man realises himself in the synthesis of three attitudes or life paths: autonomy, authenticity and selfcreation.

... Being yourself is an art, not fulfilling ready-made prescriptions. Each of us must discover our own path, because our stories, temperaments and circumstances of our lives are different, which are the matter of our life choices. ${ }^{2}$ 
Every man who is true to himself recognises that life makes sense. This means that man is satisfied with himself, although as Baruch Spinoza used to say, this feeling is probably the most difficult to achieve in reality.

\section{Architectural object}

The beauty of the creative design of the shaped architectural work is composed of several layers of meaning, i.e.

- the accuracy of defining its application programme in the shaped space, allowing for the belief that it will be fully accepted by its user;

- the ability to specify the concept of the space being shaped, to extract an individual character in relation to the environment, to highlight and highlight its values;

- defining a form allowing full identification of the dominant functions performed in the facility and its surroundings.

Programme arrangements are the basis for undertaking project activities. A wrongly programmed object will not fulfill its function or it will fill it partially. What captivates the user of the shaped space is often associated with the form of the perceived object, its originality and individuality. The architectural object often becomes the artist's identification card, representing his own approach of shaping the form. It is obvious that we prefer the readability of functions shaped in the space of our surroundings. It is not desirable to guess them. The object should be a showcase of its functions.

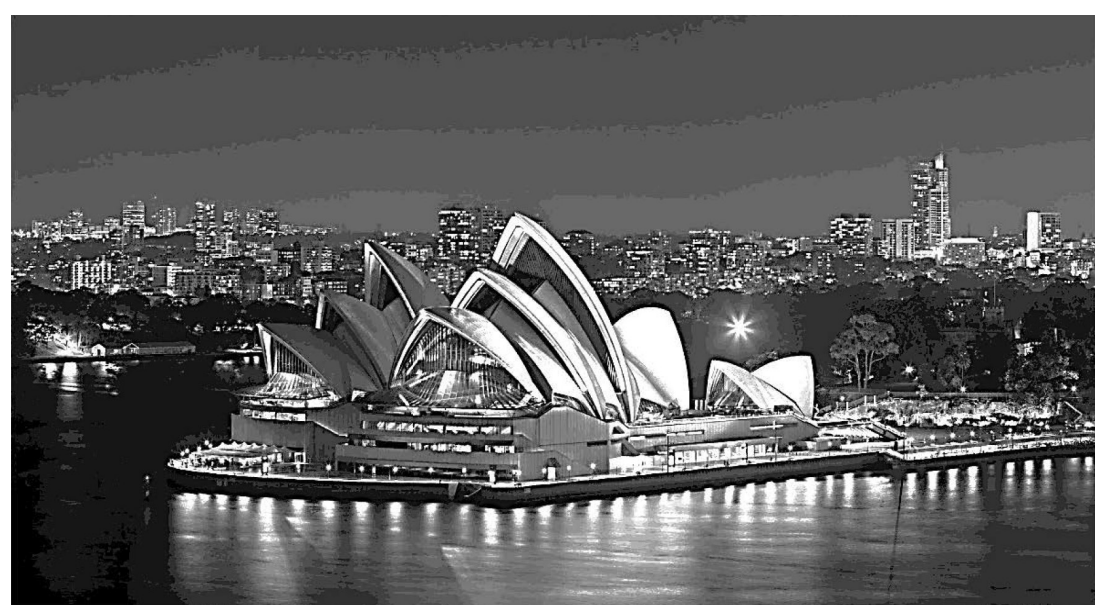

Fig. 2. Sydney Opera House One of the most recognized and beautiful architectural buildng all othe the world even during the night. Author's elaboration on the basis of illustration published in: https://pl.wikipedia.org/wiki/Sydney_Opera_House\#/media/File:Sydney_Opera_House_Dec_2008.jpg. 
Sometimes you can meet with the statement how a beautifully defined object fits functionally in the environment (it complements the already existing functions), stands out with an individual form and at the same time indicates the functions implemented in it.

The man learned to build in a way that would make it possible to distinguish a residential object from a publicbuilding, an industrial plant from an education facility, etc. The identification of the object's function in space is essential for maintaining proper communication as well as the proper orientation of the space. Despite repeated functions in the shaped space, each of the designed houses should have individual features allowing their proper identification by users. The proper identification of architectural objects is also influenced by the varied needs of people implementing them in a suitably shaped space. Although architectural objects may represent the same specific function, they differ beautifully - they implement diverse, individual needs of future users. Typical projects do not actually exist, because they are not a response to the specific needs of the investor.

2) The Ability of Determineing the Right Place for the Planned Investment, Harmonising Architecture in the Space of the Location with Particular Emphasis on the Natural Environment

\begin{tabular}{|l|l|}
\hline MAN & ARCHITECTURAL OBJECT \\
\hline The beauty of material goods sharing. & $\begin{array}{l}\text { Harmony of the place of the location with the } \\
\text { intended investment purpose; Appropriate } \\
\text { furnishing of the plot and facility with tangible } \\
\text { goods. }\end{array}$ \\
\hline
\end{tabular}

Man

One of the natural human needs is the status of possessing goods necessary for the individual's proper development. During fetal form - the unborn human being "receives into ownership" the body that he will use until the death. The child receives clothes and toys from parents, own room with age where he does school tasks, and makes contacts with friends. As soon as he completes education and reaches maturity, he takes a job to obtain funds for starting his own family, buying a flat or a house, everyday objects, etc. In spite of the pathological cases of people striving to have as many material goods as possible, whose disposal is an end in itself, people usually acquire those material goods 
that are necessary for practicing the profession, the proper functioning of the family, improving or facilitating everyday activities. Acquiring these positions contributes to the feeling of security, psychological comfort allowing the activation of mechanisms that trigger the need of a higher order: resulting from the desire to know the world, prevailing traditions and customs, seeking the meaning of life, etc. Above all, from the ethical point of view the most essential for a human being is how acquired material goods are sharing.

\section{Architectural object}

'Designing places never starts with a "blank piece of paper" and requires taking into account many existing factors. ${ }^{3}$

The three-component space model described by Tim Cresswell consists of: (1) geographically determined "location" (location), (2) physical formation of the locale and (3) "sense of place", where users live. ${ }^{4}$

The harmony of the location with the planned investment objective is one of the most important conditions for the success of the investment, for getting friendly relations with the environment. Spatial planning is the art of selecting locations for planned functions. Records of local spatial development plans should become a real signpost of the planned investment projects location. In many cases, the investor does the opposite. First, he tries to buy a plot of land (while looking for the cheapest areas), often without knowing what objects he would like to implement, and then making decisions on the implementation of a specific project, often remains in dispute with the local plan, enforces their correction. Buying the plot is not enough. It must be equipped with technical

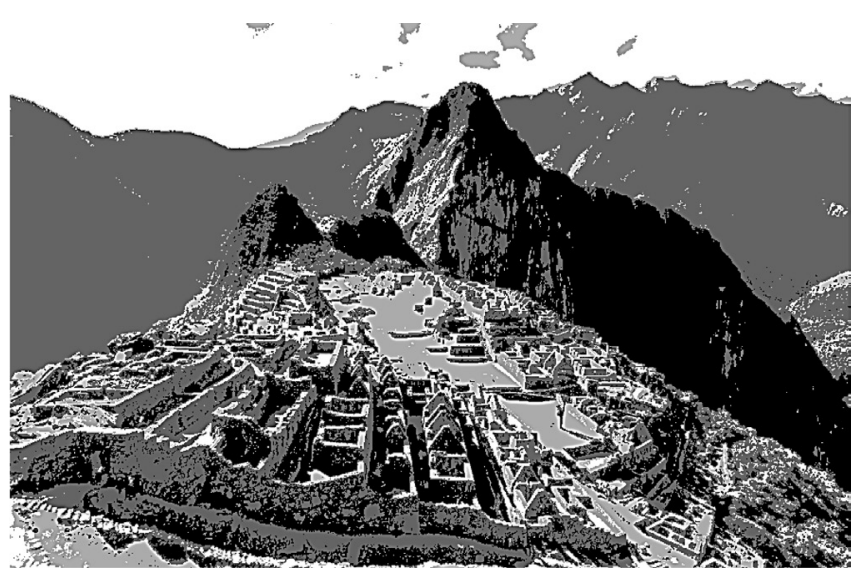

Fig. 3. Machu Picchu is the most famous and beautiful location of the preserved Inca cities. It is located in terraces on the slopes of mountains rising above 2,000 meters above sea level. Archaeological and historical value as well as amasing views attract several hundred thousand tourists every year. It is considered one of the wonders of the world. Machu Picchu is inscribed on the UNESCO list. Author's elaboration on the basis of illustration published in: https://podroze.onet.pl/ciekawe/ najpiekniejsze-budowle-swiata-cuda-architektury/9f8v4te\#slajd-2. 
infrastructure leading to the planned facility, necessary utilities, often fences, and the installation of security systems to protect the property from burglers. . When the task is completed, it is first equipped with the necessary machines, devices and furniture allowing for the proper use of the facility. Proper location of the object allowing to obtain the expected profits from the functioning of the investment, proper equipment of the building being implemented, streamlining the activities carried out in it, create the basis for the feeling of safety and comfort of its users. In the presence of the premises described here, the impression of a harmoniously entered object in the surroundings or perfect equipment may appear among people using the facility. These features give the splendour and popularity of such shaped architecture. However, in everything, yes, and here, moderation must be respected. The excessively developed territory of the plot, which is the depletion of the dwindling resources of space, irrational retrofitting of the object causes the necessity to incur unjustified economic outlays for the purchase and maintenance of furniture, devices, etc.

\section{3) Ensuring Efficient Communication with the Environment}

\begin{tabular}{|l|l|}
\hline MAN & ARCHITECTURAL OBJECT \\
\hline $\begin{array}{l}\text { The beauty of human contact with one's } \\
\text { neighbour and the immediate surroundings; } \\
\begin{array}{l}\text { The beauty of meeting people and the world; } \\
\text { The beauty of sharing your own experiences } \\
\text { with your loved ones. }\end{array}\end{array}$ & $\begin{array}{l}\text { The beauty of the communication links } \\
\text { between the object and the environment. }\end{array}$ \\
\hline
\end{tabular}

Man

Each of us lives in constant contact with the immediate surroundings. The relationships are reciprocally incorporated. Nature provides us with the air, water and food necessary for life, it is also a source of experience in mutual contacts. Man identifies himself with his immediate surroundings when he meets, understands and shapes his own needs. Establishing contact with the immediate surroundings is indispensable for each of us. You can not "stay in place". The essence of human existence is to experience and gain knowledge. To achieve this goal we have to move in the space in which we live. There are various forms of human communication with the immediate surroundings: spoken through words of thought, gestures, written words, statements in the field of art, music, etc. Each of them, in its essence, may have a different purpose, trivial conversation, exchange of views, self-advertisement, expressing opinions, etc. 
Every limitation of human freedom in the possibilities of communicating with the environment leads to the impoverishment of experiences that a person wants to experience during his life, as well as to his isolation and alienation.

The harmony of human contact with the outside world leads to the feeling of its beauty, similarly friendly relations with loved ones are a testimony to the beauty functioning between people.

\section{Architectural object}

It seems that in the discussed issue it's possible to see beauty in the functioning of communication links between the object and the environment.

The architectural object does not function without communication links with the immediate surroundings, implemented by means of pedestrian and vehicular routes, and the possibility of using parking spaces located in the vicinity of the location. Contact with the immediate surroundings also means opening to public spaces located in the immediate vicinity of the facility, offering places for meetings and rest, for the implementation of cultural events, equipped with a calm and balanced advertising and public information about important aspects of the residents' life. Communication with the nearest surroundings are also public transport stops, taxi stands, bike rentals. The architectural object is located on a building plot with its number. The street at which it is located has its own name, the building number indicates on which side of the street it is located, and also which is in order of the others. It is often possible to meet his plan on the streets of the city, on which are the locations of the most important

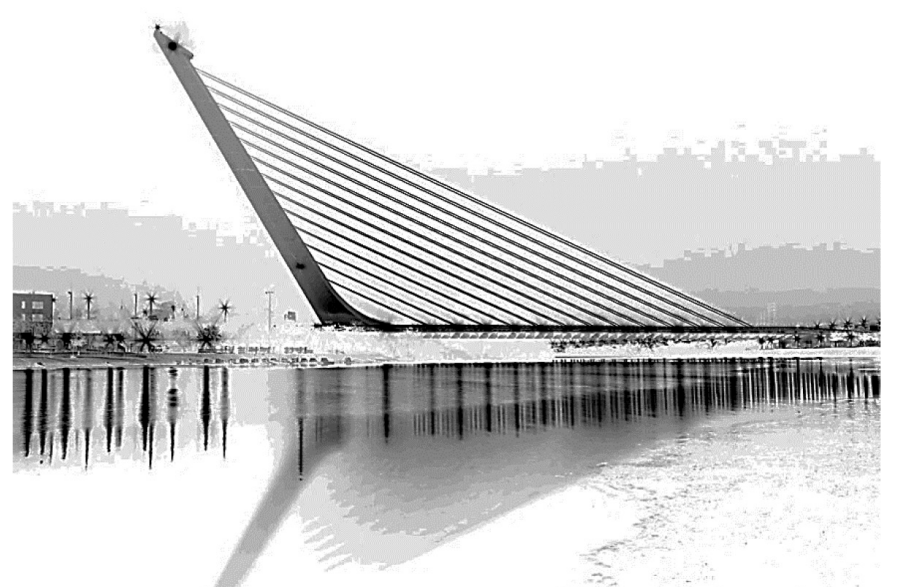

Fig. 4. The beautiful suspension bridge over the Guadalquivir River (1992) in Sevilla, architect Santiago Calatrava. Sometimes buildings are the communication itself. Author's elaboration on the basis of illustration published in: https://pl.wikipedia.org/wiki/Puente_del_Alamillo. 
objects, along with pedestrian and vehicle communication enabling collisionfree access to them. The immediate environment is also natural, if it is small (eg due to investing in the downtown area), at least it should contain accents of greenery, accompanying or in the form of ponds, fountains, etc.

The communication of the architectural object with the immediate surroundings may have the characteristics of beautiful functioning of communication links, easy access (including for the disabled), commonly available information about what is happening or will take place in the future inside the building.

\section{4) Respect for Tradition and Customs, Cultivated in the Local Socio-Cultural Environment, Paying Attention to the Historical Continuity and Coherence of the Architectural Forms Used}

\begin{tabular}{|l|l|}
\hline MAN & ARCHITECTURAL OBJECT \\
\hline $\begin{array}{l}\text { Beauty resulting from family traditions; } \\
\text { Beauty resulting from a sense of security. }\end{array}$ & $\begin{array}{l}\text { The beauty of reference to the form of the } \\
\text { object to the current tradition and customs; } \\
\text { The beauty of growing an object "from the } \\
\text { place of location", the beauty of the continuity } \\
\text { of historical forms. }\end{array}$ \\
\hline
\end{tabular}

Man

For many people, nothing is more beautiful than maintaining traditions cultivated in the family. These may result from cultivating religions, regional customs, oral traditions of the older generations, etc. The customs prevailing in the family form the basis of its consolidation, the sense of unity, and the sense of safety.

A man wants to feel safety in his contact with the surroundings. Usually, it is a feeling of confidence that something he does in a way that his environment expects of him. It is also the conviction that these activities are performed in a correct manner. In many cases, experience and appropriate qualifications are needed in this area. To possess the expected competencies, you need to work hard on them, some actions have to be repeated to become a master. Repetition is essential in the learning process. Each obtained knowledge, whether at school or on a course, must be repeated often enough to master it.

With regard to the simplest, each person builds his sense of security based on the knowledge of the elderly, parents, guardians, people who have already acquired the appropriate amount of knowledge and experience, which they could share or help on their basis. 


\section{Architectural object}

The architects themselves are also blamed for the low quality of space, who are not forced to analyse the surroundings and too often submit to modern design trends in the world architecture or to investors' advice. This results in the realisations that do not take advantage of the potential contained in the traditional development of the region. Accidental buildings are created, often designed in a style that refers to other regions of Poland or other cultural circles. ${ }^{5}$

From the first year of studies in the field of architecture, students learn about the history of architecture and urban planning. Solutions that once worked and gave an elementary sense of safety, stability, mental comfort, or lack of danger are remarkable and maintained.

The reference of the object's form to tradition, the creation of relationships with the environment based on locally binding habits of building, contributes to maintaining the cultural continuity of the place. Building without unions with the past is shaping space without tradition. Each generation inhabiting a given space creates characteristic relationships between its culture and shaped architecture, transforming into the characteristic features of regional architecture related to:

- maintaining specific forms of building,

- using specific construction materials (usually of local origin).

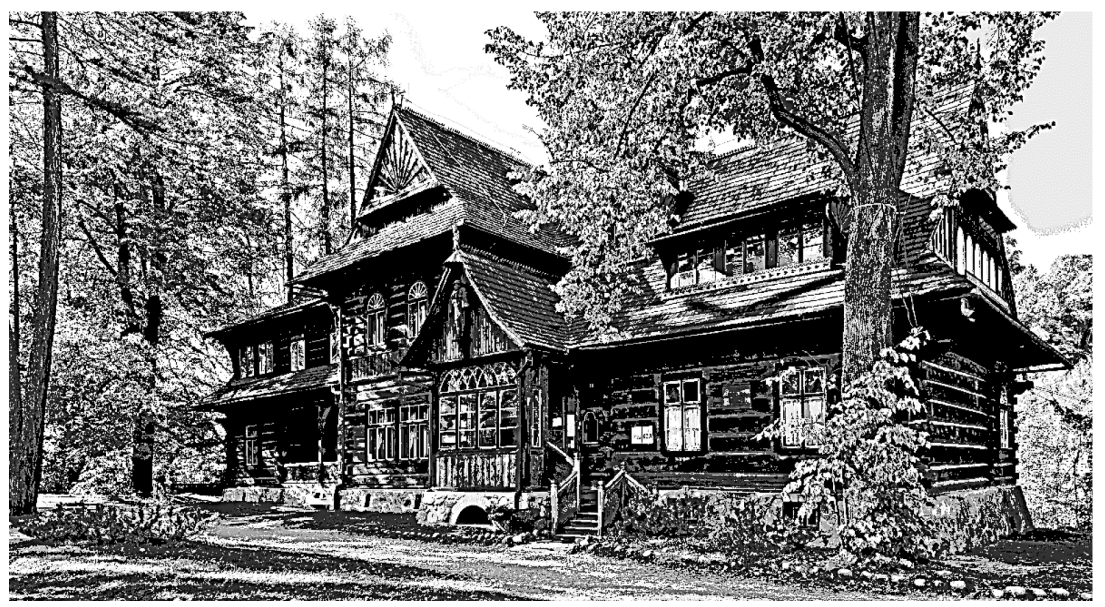

Fig. 5. Villa "Koliba" - one of the unique, beautiful examples of the monument of wooden regional architecture in Podhale (Poland) Photo: By Piotrekwas - Own work, CC BY-SA 3.0 pl. Author's elaboration on the basis of illustration published in: https://commons.wikimedia.org/w/index. php?curid=16763627. 
Shaping the form based on the experiences of the generations preceding us, related to the place and beliefs of the local community, creating a sense of homeliness, being at home and safe and fulfilling life tasks, is unfortunately now a vanishing beauty of continuity and uniformity of historical forms, the beauty of the regional landscape.

\section{5) Creativity of Shaping Space}

\begin{tabular}{|l|l|}
\hline MAN & ARCHITECTURAL OBJECT \\
\hline $\begin{array}{l}\text { The beauty of individual creation, the } \\
\text { initiation of creative acts. }\end{array}$ & $\begin{array}{l}\text { The beauty of creating new functional and } \\
\text { spatial solutions based on the transformation } \\
\text { of existing forms. }\end{array}$ \\
\hline
\end{tabular}

\section{Man}

Each of us have our own predispositions to develop specific talents. Those of us who multiply our efforts can expect fruitful results. Man's passive attitude towards the world around him leads to his inner impoverishment. In the depths of our hearts, each of us wants to be in our creative life, perceived by surroundings as a creative person. The feeling that we have done something new, original, creating the basis for new, interesting solutions is very much needed. It builds our value and hopes that our lives will be fruitful for ourselves and our fellow men. It also creates the basis for feeling the beauty of creative life which we lead.

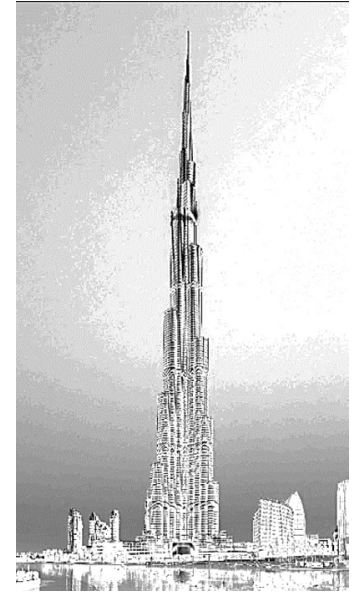

Fig. 6. Burj Khalifa, with a total height of 829.8Fig. 7. $\mathrm{m}$ built 2008. Author's elaboration on the basis of illustration published in: https:// en.wikipedia.org/wiki/Burj_Khalifa.

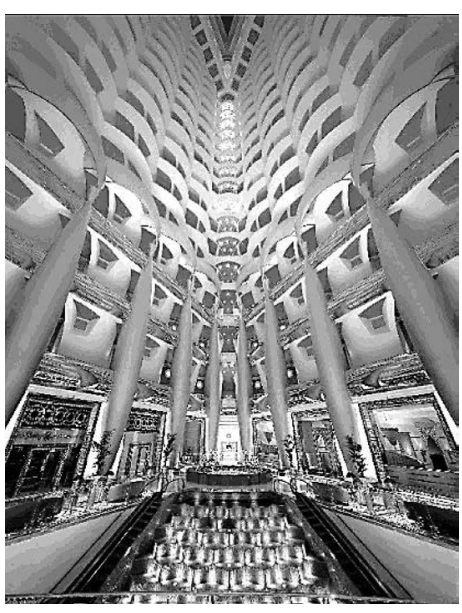

Burj Khalifa, the main hall, inside view. Author's elaboration on the basis of illustration published in: https://m. forocoches.com/foro/showthread. 


\section{Architectural object}

'Architecture is an inspiring atmosphere and beauty. It is a passion for creating for people in context time and place, nature and culture', motto of Konior Studio design studio. ${ }^{6}$

Although the use of traditional forms functioning in a given environment is a distinctive feature of homogeneous shaping of architecture, it is time to make changes that not only cause a more beneficial entry of the object into the environment, but also have a positive impact on the users of the shaped space. In the extreme case, the author of the newly designed object can completely break with the existing tradition, create a vanguard of the avant-garde, which after a certain time will be perceived as something brilliant, a milestone in shaping architecture or urban planning. This does not mean that this type of action is doomed to failure. The history of architecture is full of examples of objects that were initially unacceptable and later became the symbols of the place where they come from (the Eiffel Tower in Paris). Today we build objects much more taller. Many of them have symbolic forms inspired by the natural environment and rich transformed historical details which we can find inside the buildings (Burj Khalifa, 2010 designed by American architect Adrian D. Smith).

The beauty of architecture, which despite the use of traditional forms strongly affects the environment, introduces new details shaped by creative historical processing, is the effect of implementing new technologies based on a modification of the previously tested and recognised as safe, is usually perceived as a result of fascination, admiration or admiration.

\section{6) Precision and Innovation of the Functional and Used Spatial Solutions}

\begin{tabular}{|l|l|}
\hline MAN & ARCHITECTURAL OBJECT \\
\hline $\begin{array}{l}\text { The beauty of work focused on the need to } \\
\text { better adapt to living conditions. }\end{array}$ & $\begin{array}{l}\text { The beauty of adapting solutions to events that } \\
\text { may occur in the future, improving the sphere } \\
\text { of operation of the object leading to precision, } \\
\text { consistency and internal harmony of shaped } \\
\text { functions; } \\
\text { Accuracy and detail in solving architectural } \\
\text { and construction details; } \\
\text { The beauty of object's construction. }\end{array}$ \\
\hline
\end{tabular}


Prevention is a trait of a man caring for his fate, for the result of events that are to occur in the future, for proper preparation for accidents to occur. This feature is the driving force behind activities leading to many improvements in the sphere of human activities. Thus, man adapts better to living conditions.

\section{Architectural object}

Architectural detail is a separate spatial form interacting with the basic structure of the building and integrated with it into an inseparable whole. ${ }^{7}$

Currently, it is difficult to decorate with decorative forms. Contemporary architecture uses the achievements of technology and science, it has departed from the inspections of past epochs. Beauty of the construction was discovered, rejecting ornamentation. The detail is therefore the individual elements of the building, such as: construction, façade finishing, windows, balustrades, etc. These elements in the past also existed, but with the richness of sculptural forms (ornaments, friezes), they were not picked up in the context of eye-catching detail. ${ }^{8}$

The architect must be ahead of time, anticipate the conditions that will prevail in the period of use of the space he shapes. The time advance operation must lead to improvements in the sphere of the functioning of the facility, the achievement of a state in which the conditions created will be able to meet the requirements of the future user. The existing difficult local conditions may become the cause for searching for completely new solutions. New innovative solutions are still ahead of us. Their complexity will be increasing, involving the integration of many

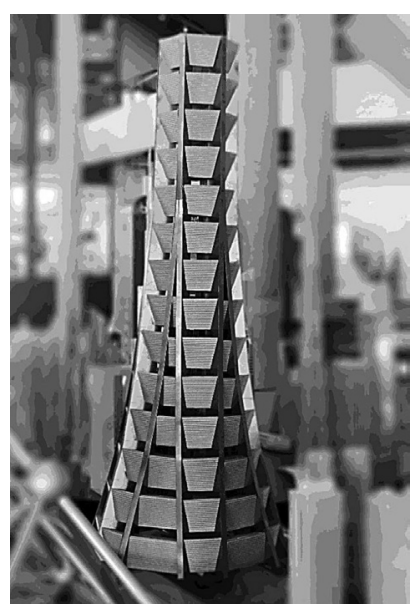

Fig. 8. Model of Sky-city. Author's elaboration on the basis of illustration published in: https://www.flickr.com/photos/ klaasfotocollectie/27671231663/
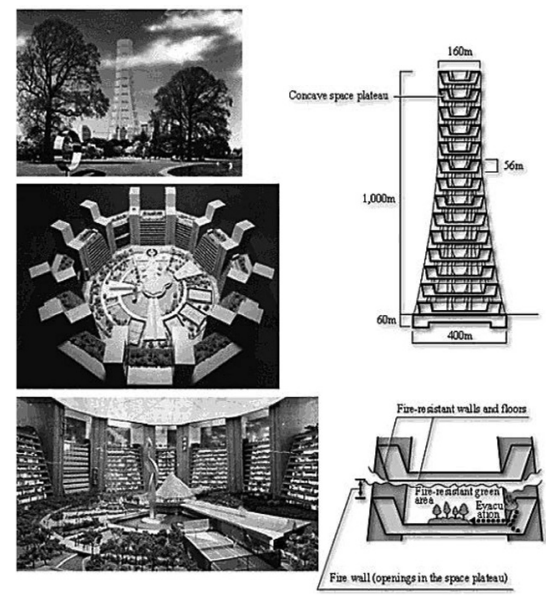

Fig. 9. Sky city author Shizuo Harada, Tokyo (Japan). Author's elaboration on the basis of illustration published in: http://utopicus2013. blogspot.com/2013/05/not-tall-enough- 
technologies, computerisation of the production of building elements, building and ultimately the management of the investment project. This interdependence and interdisciplinary nature of many fields of technology harnessed in the investment process requires precision of meticulousness and efficiency in the joint activities of engineers and technicians who are specialists in various industries. Shizuo Harada and his "Sky City" - a kilometer-high skyscraper, which aim is to replace the entire district in Tokyo, to regain space in the city intended for recreation, is an example of innovative thinking about shaping the modern city. Poor soil, unprecedented construction loads, earthquakes, wind loads, threats resulting from the event of a fire, gas explosion or terrorist attacks are factors that influence the need to search for unusual, individual solutions that can meet such challenges - beautiful, simulated by computers, but until now unverified in reality. Supertall towers as landmarks and points of reference create symbols of growth and development of urban areas, and represent the visual character of a city.

\section{7) Dialogue and the Partnership Relationship with the Neighborhood}

\begin{tabular}{|l|l|}
\hline MARRIAGE & $\begin{array}{l}\text { AN OBJECT IN AN } \\
\text { ARCHITECTURAL COMPLEX }\end{array}$ \\
\hline $\begin{array}{l}\text { The beauty of relationships taking place in a } \\
\text { married couple. }\end{array}$ & $\begin{array}{l}\text { The beauty of interactions based on } \\
\text { the partnership of the object with the } \\
\text { environment; } \\
\text { The beauty of the dialog between the } \\
\text { architecture and surroundings. }\end{array}$ \\
\hline
\end{tabular}

\section{Marriage}

A mature man or women intuitively looks for his or her partner. As soon as he or her begins his life in partnership, all worries and life goals are realised jointly by both people. Everything they have achieved so far in the course of their own individual development should contribute to the interests of their married life. This can only be built in an atmosphere of mutual understanding and close collaboration. We can't talk about a successful partnership if one of the spouses enforces the conduct of the other.

The beauty of relationships taking place in a partner relationship, and it is conditioned by the need for mutual understanding and joint responsibility for the mutual fate of the spouses. In a successful marriage a balanced, harmonious dialogue takes place. 
An object in an architectural complex

Contemporary understanding of the foundations of harmonious shaping urban planning and architecture requires a profound change in human consciousness, indicating that balance ecological can only be achieved if the built environment will be fully integrated with natural and socio-cultural environment in which man will keep respect for the surrounding him in the world. To the Triad of Vitruvius: function (utilitas), construction (fi rmitas) and beauty (venustas) you need to add an environment (oikos) and functioning in it system systems (systēmatikós). ${ }^{9}$

Each architectural object co-creates together with buildings for a similar purpose a specific team (housing, commercial and service facilities, etc.). Regardless of the type of the object, each of them serves the needs of the owner himself as well as the people who, for various reasons, move inside. We can talk about the need of zoning functions that serve the hosts of the facility and those who stay as clients, guests or simply being occasional in the object.

In addition to the function, the object interacts with its appearance. Excessive accentuation of newly designed objects may cause dissonance with the existing architecture. The relationships are returnable, often the environment triggers a negative impact on the object. The balance of mutual interactions is the basis for achieving harmonious relationships broadly understood partnership in the investment project.

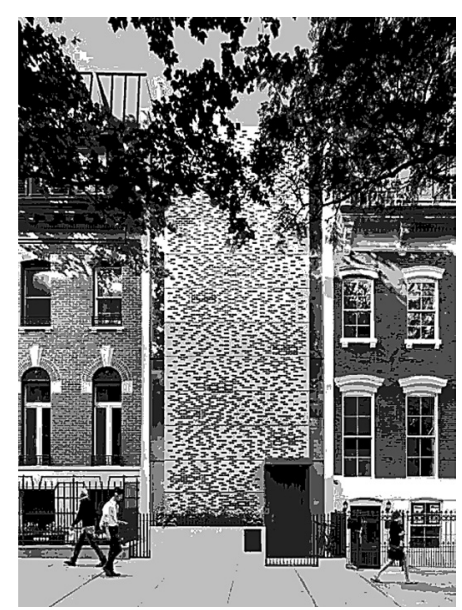


The object should conduct a dialogue with the surroundings. The object exists in the context of the environment. The beauty of the interaction based on the partnership between the object and the environment consists of socialising its function (even a single-family house has a zone for guests), weighing the attractiveness of the function and the strength of the form expression.

The dialogue of architecture with the environment is harmony with the natural and socio-cultural environment, it is a system of mutually interdependent, each other supporting interactions.

\section{8) Broadly Understood Participation in an Investment Project}

\begin{tabular}{|l|l|}
\hline FINANCIAL PARTNERS & $\begin{array}{l}\text { AN OBJECT IN AN ARCHITECTURAL } \\
\text { COMPLEX }\end{array}$ \\
\hline $\begin{array}{l}\text { The beauty of sharing and managing the } \\
\text { common state of ownership; } \\
\text { The beauty of joint investment. }\end{array}$ & $\begin{array}{l}\text { The beauty of the object's functioning in the } \\
\text { architectural complex. }\end{array}$ \\
\hline
\end{tabular}

\section{Financial partners}

The partnership means that the current property acquis of each shareholder becomes part of the joint acquis. Shareholders jointly decide about their state of ownership, make decisions about investing, selling their goods, etc.

The capital that is the basis for the operations of individual companies can be combined. Many companies decide to undertake joint investment efforts because they cannot do it independently.

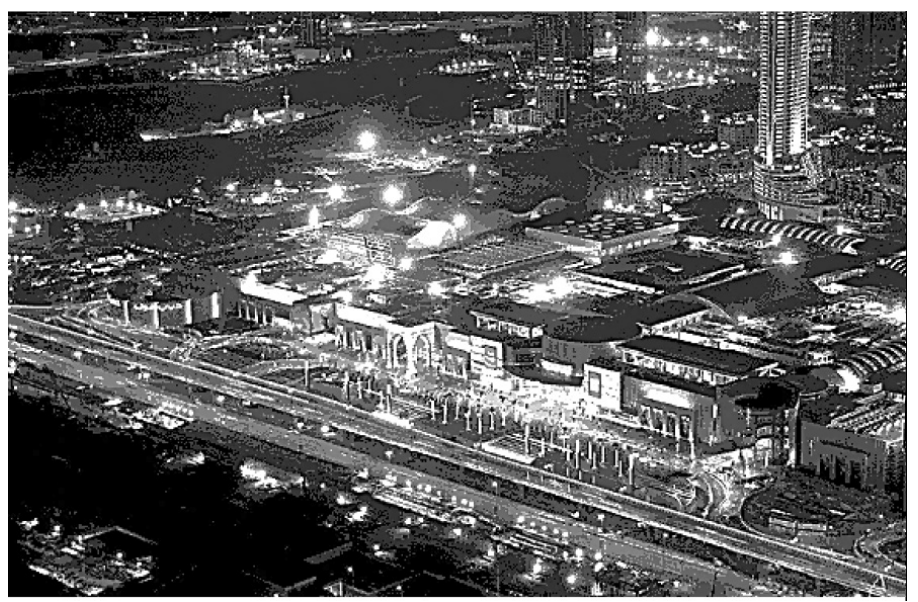

Fig. 11. Joint venture of Consolidated Contracors Company CCC and Dutco Balfour Beatty. Considered to be one of the largest shopping malls in the world, the Dubai Mall is the ultimate entertainment destination. Author's elaboration on the basis of illustration published in: https://www.ccc.net/project/ the-dubai-mall/. 
The ability to acquire material resources together, share and manage them is a beautiful feature of people working together - in a company, a consortium, a holding company, etc.

\section{An object in an architectural complex}

An architect often faces the task of planning and organising a venture funded by a team of investors. This situation is difficult because it usually involves distinguishing several individual properties for functional objects separately, but at the same time constituting one organism. Often, the free market triggers the need to organise a construction site for several contractors. This leads to the need to synchronise their activities on one building site, dividing duties and responsibilities for the necessary tasks. The common organisation of the ownership during planning and execution of the investment can go to the operational phase or the management of an architectural object. The project foreseeing the possibility of conducting investments, exploitation or management by many investors requires a careful division of roles, sometimes designation of separate land properties and architectural objects belonging to them, which in their entirety form a compact architectural object. The architect in this process plays a very important role. It may turn out that the negligence consisting in the inability to divide the real estate into a given number of properties assigned to particular investors will not be conducive to the peaceful implementation of the task. There would be no joint investments, if the contracts /agreements are not concluded previously. Linking individual objects to a group, constituting the whole functional and spatial is a kind of beauty of integration of various architectural, construction and material, technical, formal and legal problems, etc.

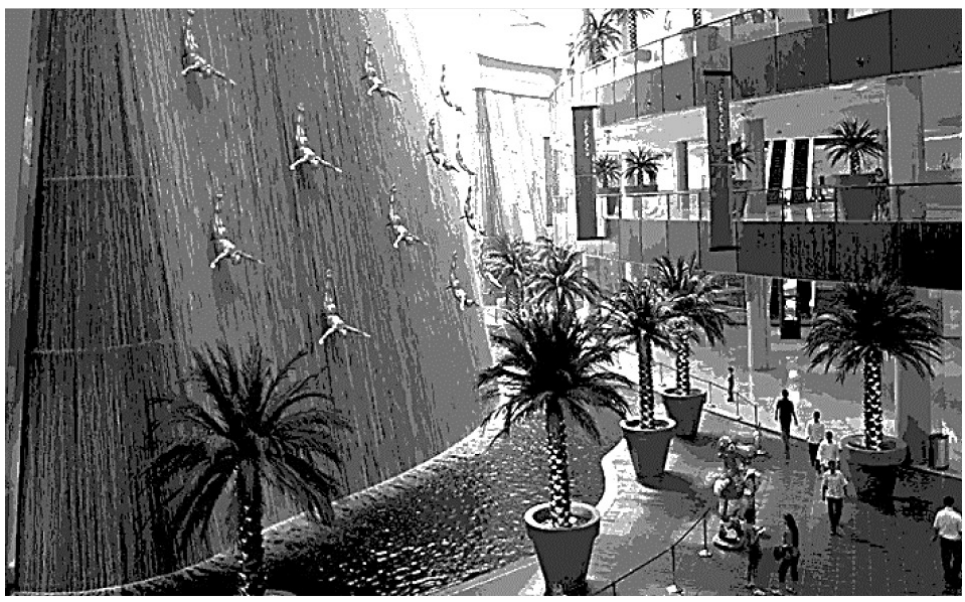




\section{9) Transmit a Philosophical Meanings Trigger Message and Transcendence}

\begin{tabular}{|l|l|}
\hline MEDITATING MAN & $\begin{array}{l}\text { OBJECT / COMPLEX OF } \\
\text { ARCHITECTURAL OBJECTS WITH } \\
\text { SIGNIFICANT CULTURAL VALUES }\end{array}$ \\
\hline $\begin{array}{l}\text { The beauty of a deeper understanding of the } \\
\text { higher hierarchy of values, abstract categories, } \\
\text { the environment, the world of ideas, symbols, } \\
\text { etc. }\end{array}$ & $\begin{array}{l}\text { The beauty of the transmission of symbolic } \\
\text { and semantic values inscribed in the form, } \\
\text { construction and material structure of the } \\
\text { object or architectural complex. }\end{array}$ \\
\hline
\end{tabular}

\section{Meditating man}

It's not enough to learn about the immediate environment for people who want to explore the value of their lives. They want to explore and develop worldviews, look for the meaning of existence, become beings as fully as possible to learn about and understand the mechanisms of functioning of the world and even the universe.

At this stage of experiencing reality, man introduces symbol systems, abstract categories allowing to describe the observed phenomena in a generalised way. This requires a new look at phenomena that have be perceiving and experienceing much far, with a "distance" view, allowing for the proper assessment of the examined things or phenomena. The practice of this type of experience is combined with the beauty depicting the generalisation of the perceived world, the perception or the cognition of the ultimate things, the approach to the spiritual world.

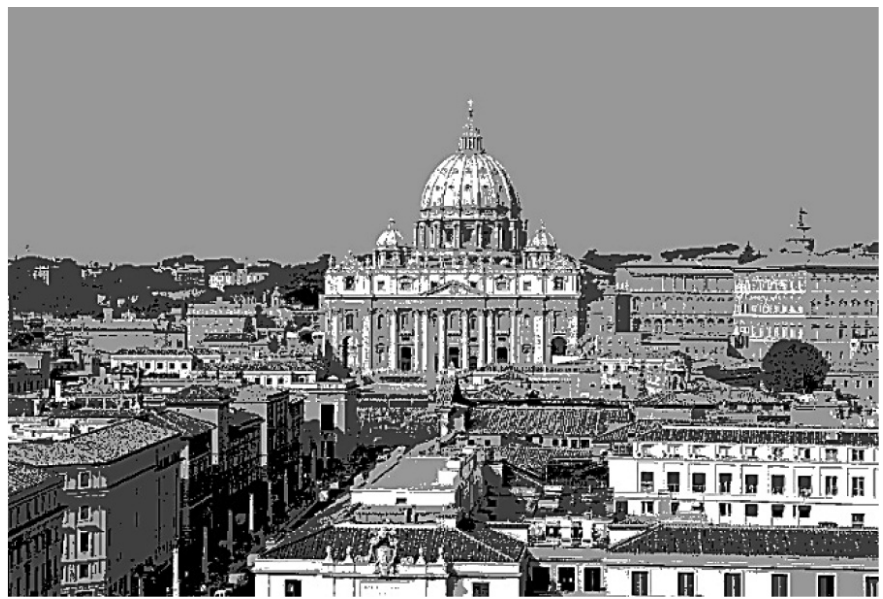

Fig. 13. Basilica of St. Peter in Rome (Jorge Valenzuela) Author's elaboration on the basis of illustration published in: https://commons.wikimedia.org/w/index.php?curid=17844482). 
Object / complex of architectural objects

with significant cultural values

Many architectural constructions have their destiny connected with the confession of faith, a place of meditation. Since ancient times, man has built temples, places of worship, performing rites, etc. Whenever we enter these objects, we find in them many images and symbols with religious content or philosophical values. These contents can also be coded by the appropriate arrangement of architectural elements. An example may be Egyptian pyramids. To this day, we read more and more new meanings and content that testify to the exceptionally high knowledge of the ancient man. Contemporary objects filled with symbolism and meanings are mainly related to sacred buildings. Both the spatial layout as well as the architectural detail are treated in a special way in these objects. The sacred space is clearly different from the profane space. The rich language of architectural forms allows us to present a variety of content related to faith, the message of the Creator himself, and the history of man's relationship with God. Such objects usually have far-reaching effects.

The beauty of an object containing deep symbolism and religious-philosophical content is very deep and unique.

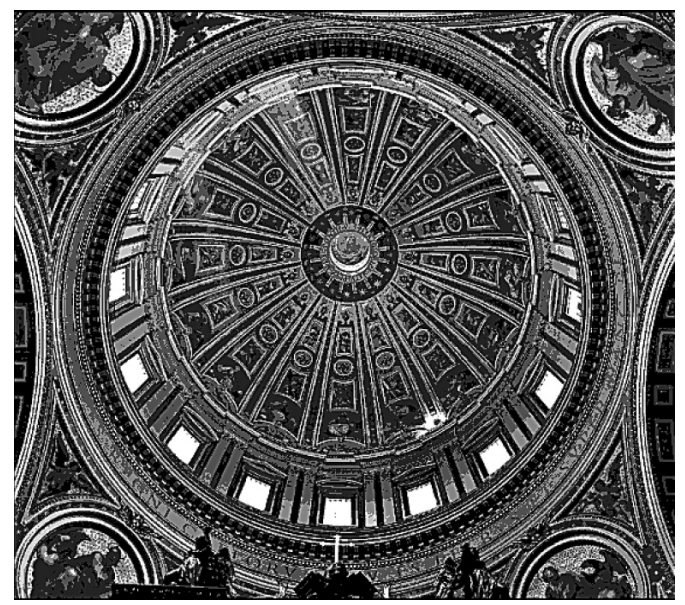

Fig. 14. The Dome of St. Peter Basilica in Rome. Author's elaboration on the basis of illustration published in: https://commons.wikimedia.org/w/index.php?curid=18513637. 
10) Proper Use and Management

\begin{tabular}{|l|l|}
\hline A MAN FULFILLING HIS ROLE / & OBJECT / COMPLEX OF \\
DESTINY IN SOCIETY & ARCHITECTURAL OBJECTS \\
\hline The beauty of realizing man's destiny. & $\begin{array}{l}\text { Beauty resulting from the implementation of } \\
\text { tasks performed by the object / complex of } \\
\text { architectural objects. }\end{array}$ \\
\hline
\end{tabular}

\section{A man fulfilling his role / destiny in society}

In the life of every person, the time comes to use the acquired knowledge and skills for a specific professional and social status. Implementing one's skills in work is one of the most important values in the life of every human being. It allows us to feel that someone needs us, that our effort is directed at things important to the community in which we live. With experience in professional work, we become experts in a given profession, share our knowledge and skills with those who need it, we pass these experiences to those who will succeed us. This state allows you to maintain certain security related to the implementation of certain services and benefits for society. The scope of these services, their availability and competitiveness allow us to think about the quality and standard of living of a given community. Everyone who makes an effort to work is subjected to specific social, political conditions, producing systems of levels and hierarchy of individual professions. Not everyone will achieve managerial positions, not everyone will be able to work in certain professions, even at the lowest organisational levels. This results not only from the required qualifications of the applicants, but also from the specific needs. The beauty resulting from fulfilling a given role in the community for many of the people is fulfilling their destiny.

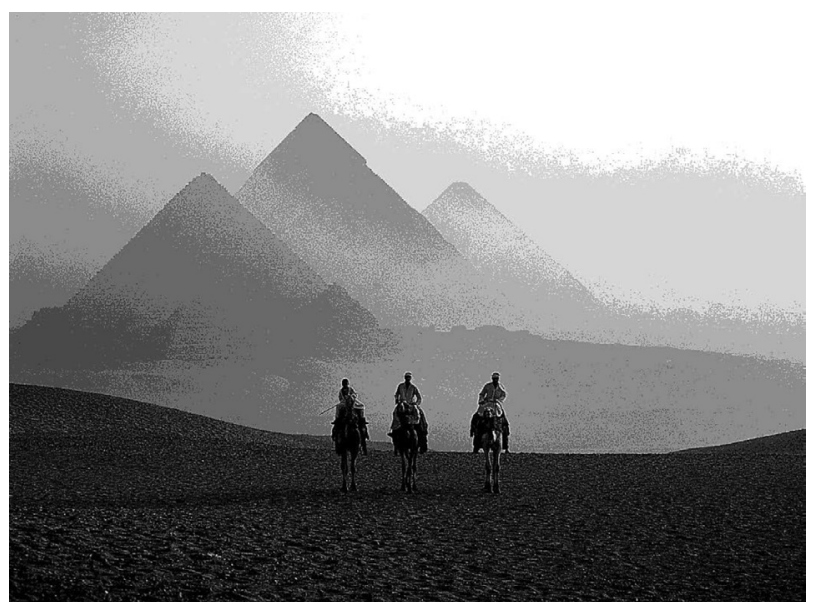

Fig. 15. The Great Pyramid in the complex of pyramids in Giza, Egypt. Although many years have passed, we can only guess the true purpose of these great objects and of course admire their monumental beauty. Author's elaboration on the basis of illustration published in: https://www.budowle.pl/ budowla,wielka-piramida. 


\section{Object / complex of architectural objects}

Architectural objects that we design, implement and use are influenced by cultural, social and political conditions shaped by a given human environment. All this means that their tasks and functions are segregated, regrouped and given a proper rank.

In many cases, the facilities are grouped into specific organisations related to education, hospitality, social and health care, etc. There is a similar phenomenon here as in the life of every human being - fulfilling a specific social role. Hence, objects requiring universal access are covered by isochrones of a specific time necessary to reach it on foot or to provide organised access (primary schools). Shaping space while maintaining the hierarchy of objects' importance is very important for a human being. An example of this is the development of the market in which the town hall raised above the surrounding buildings plays a dominant role. This creates a sense of proper identification and hierarchy of functions shaped in the human environment.

The beauty resulting from the implementation of tasks of the object / complex of architectural objects is conditioned by its proper location in the hierarchy of objects constituting its surroundings, or located in the organisational grid of the team formed by objects with similar functions. The above example also shows a simple conclusion that not every architectural object will act as a town hall, it results not only from the place where it can be implemented, but also the demand for such objects in society.

Proper regionalisation of functions, logic of the availability of functions (pedestrian access isochrones, individual and mass circular communication), fulfilling the expected role of the object in the community (rural, urban, agglomeration, region, state) are the premises supporting the above defined beauty.

\section{1) Achieving Social and Cultural Goals}

\begin{tabular}{|l|l|}
\hline A MAN ACHIEVING LIFE GOALS & $\begin{array}{l}\text { ARCHITECTURAL OBJECT ACHIEVING } \\
\text { INTENDED SOCIO-CULTURAL } \\
\text { INVESTMENT OBJECTIVES }\end{array}$ \\
\hline $\begin{array}{l}\text { The beauty of sharing place in the outside } \\
\text { world with neighbour and all what is close } \\
\text { to us. }\end{array}$ & $\begin{array}{l}\text { Beauty resulting from realising the purpose of } \\
\text { the object / complex of architectural objects. }\end{array}$ \\
\hline
\end{tabular}




\section{A man achieving life goals}

Everyone, regardless of their social status, wants to be creative and to leave something behind. Otherwise, our role would be to uncritically reproduce activities performed by others.

Individual human creativity is now to reflect on the level of social forms of existence. This activity, transforming into international movements, may even have a general human character.

\section{Architectural object achieving intended socio-cultural investment objectives}

Shaping space involves determining the living conditions for many social groups, interrelated relations arising from professional relations (administration, manual workers, white-collar workers, people staying as clients). Often, many of these groups share one architectural object. Each of them requires the fulfillment of appropriate technical and functional conditions.

This results in the necessity of prudent programming and designing of functions in such a way that satisfaction with the use of the object would be possible for all social groups. As such, an object as fulfilling the expectations of its users achieves the purpose of its existence.

Sometimes the buildings aim to commemorate important events, achieved goals in the history of the nation. They express the beauty of the goal achieved by the nation and they usually become the image of beauty positive international influence.

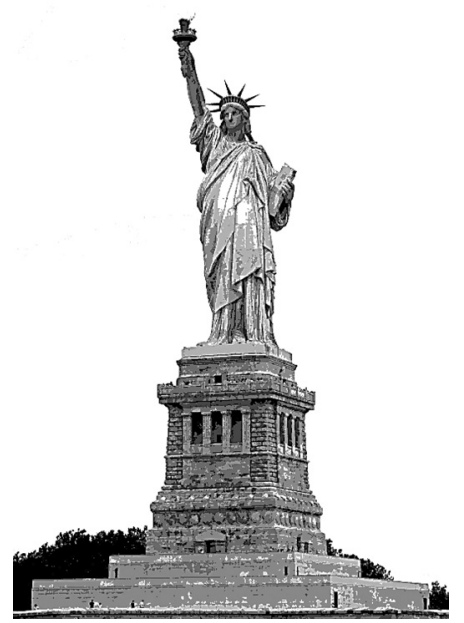


The Statue of Liberty is a figure of Libertas, a robed Roman liberty goddess. She holds a torch above her head with her right hand, and in her left hand carries a tabula ansata inscribed in Roman numerals with "JULY IV MDCCLXXVI" (July 4, 1776), the date of the U.S. Declaration of Independence. This statue, one of the largest in the world, was donated by France to the United States.

\section{2) Ability to Plan and Transform / Revitalize Investments}

\begin{tabular}{|l|l|}
\hline $\begin{array}{l}\text { MAN AT THE END OF LIFE } \\
\text { EXPERIENCES }\end{array}$ & $\begin{array}{l}\text { OBJECT/COMPLEX OF ARCHITECTURAL } \\
\text { OBJECTS AT THE END OF TECHNICAL } \\
\text { LIFE EXHAUSTION }\end{array}$ \\
\hline $\begin{array}{l}\text { Beauty resulting from the summary of the } \\
\text { experiences of life and making decisions } \\
\text { about further personality development. }\end{array}$ & $\begin{array}{l}\text { Beauty resulting from the renovation of } \\
\text { architectural objects and revitalization of } \\
\text { urban complexes. }\end{array}$ \\
\hline
\end{tabular}

Man at the end of 1 ife experiences

The end of the cyclic process of accumulation of human experiences can also be a success and the beginning of a new cycle at a higher level of consciousness or a loss, which disintegrates the system of existing values and the necessity to re-accumulate basic life experiences. This time in human life is often a period of anxiety. When something in life ends, it is time to sum up what was good and what was bad. Something in human life is about to start again, having rich experience from the previous phases - there is a chance that the tasks that have been resumed will be carried out with a better result, and greater benefits for those who participate in them. The beauty of time during which a man sums up his own deeds of good and bad is unique. In many cases, it is time for a man to say goodbye to mortality - and to enter into eternal life.

\section{Object/complex of architectural objects \\ at the end of technical life exhaustion}

The architectural object / complex can not be used for an unlimited period of time. Sooner or later there will be a period of technical aging of the facility and the need for renovation and renovation. While the object still meets the expectations of its users - necessary repairs become only their temporary exclusion from use. Objects get older in terms of morality, after a certain period of time they no longer correspond to the needs of users due to the changing trends in our lives, lifestyles, emerging new, better opportunities to satisfy the same needs. It also happens that objects have fulfilled their role, fulfilled a specific purpose 
and their further use is devoid of being. This phenomenon causes the users to leave facilities, change owners, introduce necessary modernisations in their interiors, and in justified cases, a complete change of the function, allowing for a new restoration of the use of the object. We often discover former beauty of abandoned buildings, which can be expressed in form, detail, or other aspects referred to above.

A kind of beauty concerns industrial architecture, whose traces of old technologies, devices and machines, become a specific beautiful cultural heritage. ${ }^{10}$

The architectural concept of the shopping center "Stary Browar" in Poznan (Poland) can be defined without a doubt as very attractive, innovative, unusual and beautiful.

\section{SUMMARY}

The investment process consists of repeated stages of programming, designing, the project realisation, usage , folowed by the modernisation, revitalisation, transformation, technical death, after which the programme is usually rebuilt and the stages listed above are repeated anew. The process of shaping space resembles metabolic processes occurring in nature, similar to human development stages. Conceived life develops the body, leads a man to maturity, and after exhausting his strength, he returns to a state that allows him to be reborn and grow into a new beingto inhabit our planet. It seems that nature controls the processes of exchanging matter and energy in a way that allows

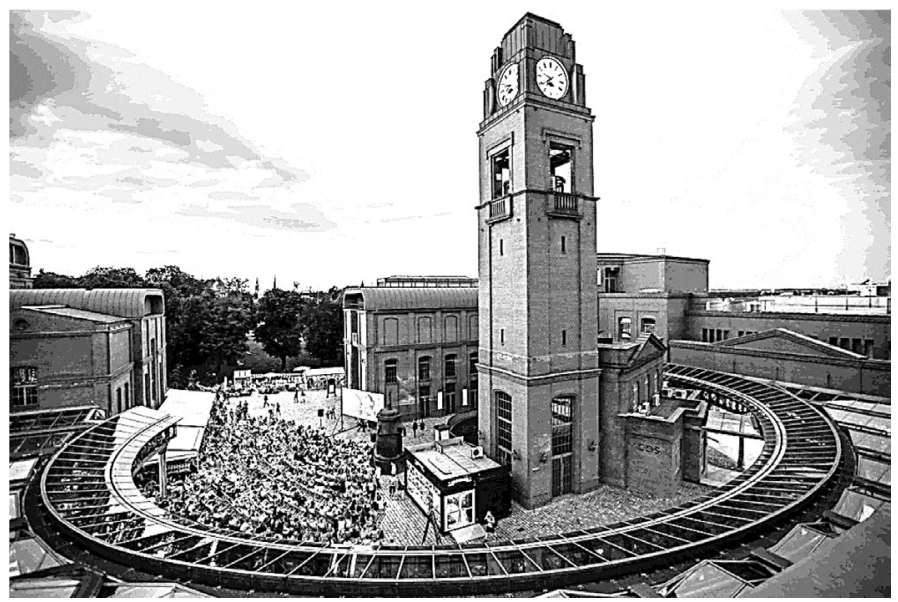

Fig. 17. Revitalisation of the district at Półwiejska Street, the large commercial center Stary Browar. Author's elaboration on the basis of illustration published in: http://www.bryla.pl/bryla/56,85301,23224177,s. $\underline{\mathrm{html}}$. 
for the renewal of the life cycle in an unlimited way. To a large extent, man can learn from nature, which (as the world of science maintains) is determined by functioning in our reality physical laws. A man who remains a part of the world of nature, despite being aware of his individuality and the unique role he plays on Earth, remains under their influence, learning the mechanisms of their actions - he tries to use them to achieve his own goals resulting from elementary human needs. All this is a testimony to the specific beauty contained in nature, the man himself and the things created by him. Architecture that is the work of human hands, as long as it serves man and it is friendly to nature, it also contains beauty. Beauty in architecture is a state of harmony of aesthetic and utilitarian values of the shaped space in the relations of a creative response to broadly understood conditions of the local, natural, socio-cultural and built environment.

There are two types of beauty:

- Subjective beauty that is revealed inside of things, and

- Objective beauty, perceived by the general, which is always visible on the outside.

It seems that the described components (criteria for the assessment of beauty) do not in themselves constitute the value of beauty in architecture, but their observance leads to the goal in which beauty can be perceived by users of the shaped space, or in a different way, regardless of whether it will be perceived in a subjective or objective way. 

metodologiczne. Available at: http://delibra.bg.polsl.pl/Content/28980/BCPS 32823 Miejscejako-cel-pro_0000.pdf (20.02.2019). architekturze Placemaking vs an open form: active perception in architecture," Czasopismo Naukowe, Kultura i Historia (2004):7. (ISSN 1642-9826, Available at: https://www.kulturaihistoria. umcs.lublin.pl/archives/5964\# ftn9); T. Cresswell, Place. A short introduction (Oxford: Blackwell Publishing, 2004), 7.

Piotr Zierke, “Odwołania do tradycji we współczesnej architekturze aglomeracji poznańskiej jako szansa na poprawę jakości przestrzeni," Acta Universitatis Lodziensis Folia Geographica SocioOeconomica 19 (2015). Aleksandra Nowicka, "Dialog z otoczeniem," Budownictwo i Architektura 11 (2012): 15-23.

Janusz A. Włodarczyk, "Detal architektoniczny, czym jest?," Available at: https://suw.biblos. pk.edu.pl/downloadResource\&mId=1074720.

Krystyna Strumiłło, "Detal w artchitekturze współczesnej,” Available at: https://suw.biblos.pk.edu. pl/downloadResource\&mId=1087616. Opolska, 2012).

Krzysztof Gasidło, "Discovring the beuty of old factors," in Beauty in architecture, ed. Szuba, Drewniak (Oficyna wyd. PWSZ w Nysie, 2018). 
Cresswell, T. Place. A short introduction. Oxford: Blackwell Publishing, 2004.

Gasidło, K.. "Discovring the beuty of old factors." In Beauty in architecture, ed. Drewniak Szuba. Nysie: Oficyna wyd. PWSZ, 2018.

http://utopicus2013.blogspot.com/2013/05/not-tall-enough-series-sky-city-1000.html (access 20.0 2.2019)

http://www.bryla.pl/bryla/56,85298,10474730,Miejskie_plomby.html (access 20.02.2019)

http://www.bryla.pl/bryla/56,85301,23224177,s.html (access 20.02.2019)

https://en.wikipedia.org/wiki/Burj_Khalifa (access 20.02.2019)

https://m.forocoches.com/foro/showthread.php?t=4434821) (access 20.02.2019)

https://pl.wikipedia.org/wiki/Puente_del_Alamillo (access 20.02.2019)

https://podroze.onet.pl/ciekawe/najpiekniejsze-budowle-swiata-cuda-architektury/9f8v4te\#slajd-2

(access 20.02.2019)

https://www.budowle.pl/budowla,wielka-piramida (access 20.02.2019)

https://www.ccc.net/project/the-dubai-mall/ (access 20.02.2019)

Lasiewicz-Sych, A. Miejsce jako cel projektowania: Założenia teoretyczne i uwagi metodologiczne. Available at: http://delibra.bg.polsl.pl/Content/28980/BCPS_32823_-_Miejsce-jako-cel-pro_00 00.pdf (access 20.02.2019).

Lasiewicz-Sych, A.. "Kreacja miejsc a forma otwarta: problem aktywnej percepcji w architekturze Placemaking vs an open form: active perception in architecture." Kultura i Historia (ISSN 16429826, Available at: https://www.kulturaihistoria.umcs.lublin.pl/archives/5964\# ftn9 (access 20.02.2019)).

Nowicka, A. "Dialog z otoczeniem,” Budownictwo i Architektura 11 (2012): 15-23.

Old Testament, Song of Songs (4.1-5, 5.10-16).

Strumiłło, K. "Detal w artchitekturze współczesnej," Available at: https://suw.biblos.pk.edu.pl/ downloadResource\&mId=1087616 (access 20.02.2019).

Szuba, B. Systemy środowiskowe a lokalne otoczenie człowieka. Wyd. Politechnika Opolska, 2012.

Włodarczyk J. A. "Detal architektoniczny, czym jest?,” Available at: https://suw.biblos.pk.edu.pl/ downloadResource\&mId=1074720 (access 20.02.2019).

Workowski A. "Sztuka bycia sobą." Czasopismo Znak 704. Styczeń, 2014.

Zierke, P. “Odwołania do tradycji we współczesnej architekturze aglomeracji poznańskiejjako szansa na poprawę jakości przestrzeni.” Acta Universitatis Lodziensis Folia Geographica Socio Oeconomica 19, 2015. 
STEREOTIP LEPOTE I IZGRADNJE. ESTETIKA ARHITEKTURE.

\section{Raffaele Milani}

U ovom radu smo se bavili stereotipom kao otpornim modelom tipova stvorenih objekata, slikom proizvodnog procesa koja se ponavlja ili se može ponavljati i standardizovanim modelom virtuelnosti; drugim rečima, stereotipizacija daje formu stvarima unutar sistema objekata koji se serijski reprodukuju. Viševekovna sinteza zanatstva i materijala se u našem vremenu transformisala u dizajn. Rekonstrukcija objekta podrazumeva praćenje tehnika koje su korišćene u nastanku istog, uključujući i one tradicionalne. U pogledu odnosa medju tehnologijama, vodi se žestoka rasprava izmedju onih koji žele da brane tragove prošlosti kao sećanje koje je značajno za budućnost, kao i instrument za harmonizaciju masa, i onih koji u potpunosti favorizuju novitete hibridnog stila koji je u modi posle faze modernizma. Ovi drugi podržavaju deregulaciju proizvodnje arhitektonskih objekata i nekoherentnu, improvizovanu organizaciju prigradskog okruženja. Tokom istorije su postojale značajne razlike u mišljenju o vrednosti čovečanstva, kvalitetu života, načinima razmišljanja i oblicima kulture i umetnosti.

KLJUČNE REČI: ESTETIKA, ARHITEKTURA, UMETNOST, JEZIK, STEREOTIP, ETIKA, LEPOTA

\section{MULTIKRITERIJUMSKA PROCENA LEPOTE U ARHITEKTURI \\ Boguslaw Szuba}

Članak se bavi problemima lepote u arhitekturi koji se nalaze u raznim slojevima značenja koji se odnose na: $\left(^{*}\right)$ kreativnu ideju planirane investicije; $(*)$ sposobnost da se odredi pravo mesto za planiranu investiciju, uskladjujući arhitekturu u prostoru lokacije, sa posebnim osvrtom na prirodno okruženje; $(*)$ komunikaciju i informacije sa okolinom; $(*)$ poštovanje tradicije i običaja koji se poštuju u lokalnom socijalno-kulturnom okruženju, obraćajući pažnju na istorijski kontinuitet i koherenciju arhitektonskih oblika koji se koriste; $\left(^{*}\right)$ kreativnost oblikovanja prostora; (*) preciznost i inovativnost funkcionalnih i korišćenih prostornih rešenja; $\left(^{*}\right)$ partnerski odnos sa susedstvom; $\left(^{*}\right)$ široko shvaćeno učešće u procesu investiranja; $\left({ }^{*}\right)$ davanje značenja pokrećući filozofsku poruku i transcendenciju; $(*)$ pravilno korišćenje i upravljanje; $(*)$ postizanje socijalnih i kulturnih ciljeva; $(*)$ sposobnost planiranja transformacije / revitalizacije postojećih arhitektonskih objekata.

Istraživačka metoda je analiza navedenih komponenti na osnovu izvora iz literature i primera arhitektonskih objekata ili urbanih kompleksa.

Razmatranja vode do teze: Lepota u arhitekturi je stanje harmonije estetskih i upotrebnih vrednosti oblikovanog prostora u odnosima kreativnog odgovora na široko shvaćene uslove lokalnog, prirodnog, socijalno-kulturnog i izgradjenog okruženja.

KLJUČNE REČI: LEPOTA U ARHITEKTURI, KRITERIJUMI LEPOTE U ARHITEKTURI, HARMONIJA ARHITEKTURE I OKRUŽENJA, FILOZOFIJA ARHITEKTURE, ESTETIKA ARHITEKTURE

\section{ARHITEKTURA KAO INSTRUMENT ESTETSKE I POLITICKE MISLI Thomas SYMEONIDIS}

Uprkos uobičajenom pristupu arhitekture u smislu zamisli, dizajna i izgradnje izgradjenog okruženja, u ovom radu ističemo da se arhitektura može koristiti kao instrument estetske i političke misli. Zbog toga se oslanjamo na definicije arhitekture ističući ili njene aspekte principa (arché) ili konstrukcije ili njen relacijski karakter. S tim u vezi, arhitektura će se koristiti kao sredstvo za pitanja konceptualizacije i promišljanja na preseku dve ključne tačke političke teorije - jednakosti i pravde. 